\title{
ANALISIS PERBANDINGAN KINERJA KEUANGAN PT. BANK BRI SYARIAH MENGGUNAKAN LAPORAN LABA RUGI DAN NILAI TAMBAH
}

\author{
Mustakar Rail \\ mustakarrail@gmail.com
}

\begin{abstract}
This study entitled "Comparative analysis of the financial performance of PT. Bank BRISyariah uses profit and loss and value added statements with the aim of finding out how the financial performance of BRI Syariah Bank is based on added value and income statement. While the research method used in this research is descriptive qualitative method and will later describe the condition of the financial performance of BRI Syariah Bank. This study concludes that the financial performance of BRI Syariah Bank in the 2013 period to period

2014 experienced a significant decline, while in the following period it experienced a significant increase.
\end{abstract}

Keywords: financial performance, added value, income statement.

\begin{abstract}
ABSTRAK
Penelitian ini berjudul "Analisis perbandingan kinerja keuangan PT. Bank BRISyariah menggunakan laporan laba rugi dan nilai tambah" dengan bertujuan untuk mencari tahu bagaiaman kinerja keuangan Bank BRI Syariah berdasarkan nilai tambah dan laporan laba rugi. Sedangkan metode penelitian yang digunakan dalam penelitian ini adalah metode deskriptif kualitatif dan nantinya akan menggambarkan kondisi kinerja keuangan Bank BRI Syariah. Penelitian ini menyimpulkan bahwa kinerja keuangan Bank BRI Syariah pada periode 2013 ke periode

2014 mengalami penurunan yang signifikan, sedangkan pada periode berikutnya mengalami kenaikan yang signifikan.

Kata kunci: Kinerja keuangan, nilai tambah, laporan laba

rugi.
\end{abstract}

\section{PENDAHULUAN}

A. Latar belakang

Adanya persaingan antar bank syariah maupun dengan bank konvensional lainnya yang tidak bisa dihindarkan, membawa dampak positif dan negatif bagi perkembangan sebuah bank, 
termasuk bagi bank syariah. Dampak positifnya adalah memotivasi agar bank saling berpacu menjadi yang terbaik. Sedangkan dampak negatifnya adalah kekalahan dalam persaingan akan menghambat laju perkembangan bank yang bersangkutan. Kondisi ini akan membawa kerugian yang besar bagi bank, bahkan dapat mengakibatkan gulung tikar.

Penilaian kinerja keuangan bank syariah dapat dilakukan dengan menganalisis laporan keuangan yang diterbitkan. Salah satunya dengan menganalisis tingkat profitabilitas bank syariah yang bersangkutan, dengan menggunakan rasio Return On Asset (ROA), Return On Equity (ROE), dan rasio perbandingan antara total laba bersih dengan total aktiva produktif.

Saat ini para pengguna laporan keuangan (nasabah, Karyawan, pemerintah, masyarakat, manajemen) dihadapkan pada satu kondisi dimana laporan keuangan bank syariah belum dapat melakukan analisis terhadap kinerja keuangan bank syariah secara tepat, mengingat laporan keuangan bank syariah sebagaimana yang termuat dalam PSAK Akuntansi syariah hanya memuat elemen laporan keuangan sebagaimana elemen dalam laporan keuangan bank konvensional.

Kaitannya dengan pemenuhan akuntabilitas laporan keuangan bank syariah, dengan belum dimasukkannya laporan nilai tambah (Value added statement) sebagai laporan keuangan tambahan dalam laporan keuangan bank syariah, maka dari itu perlu diketahui bagaimana pertanggungjawabannya kepada stakeholders. Karena laporan laba rugi merupakan laporan yang lebih memperhatikan kepentingan direct stakeholders (pemilik modal), berupa pencapaian profit yang maksimal, dengan mengesampingkan kepentingan dari pihak lain (karyawan, masyarakat, sosial dan pemerintah), sehingga profit yang diperoleh distribusinya hanya sebatas kepada direct stakeholders (pemilik modal) saja. Sementara dengan adanya value added statement sebagai laporan keuangan tambahan maka kemampuan bank syariah dalam menghasilkan profitabilitas dihitung dengan juga memperhatikan kontribusi pihak lain 
seperti karyawan, masyarakat, pemerintah dan lingkungan. Sehingga profit yang diperoleh dalam distribusinya tidak hanya sebatas pada direct stakeholders melainkan juga kepada indirect stakeholders. ${ }^{1}$

Secara garis besar teori yang digunakan dalam membuat laporan keuangan bank yaitu konsep entity teory yang hanya mengutamakan kepentingan direct stakeholders (pemilik modal) saja, yang bila dikaji secara dalam banyak mengandung nilai-nilai kapitalisme dan utilitarianisme, bila dibandingkan denganSyariah Enterprise Teoryyang tidak hanya mementingkan direct stakeholders tetapi juga mementingkan indirect stakeholders (karyawan, masyarakat, sosial dan pemerintah). Karena konsep Syariah enterprise teory di bangun berlandaskan metafora amanah, metafora zakat.

\footnotetext{
${ }^{1}$ Amrullah reza putra tara,Analisis perbandingan kinerja keuangan perbankan syariah menggunakan pendekatan laba rugi (income statement) dan nilai tambah (value added statement),op.cit.,h.8
} 
Syariah enterprise teory memiliki cakupan akuntabilitas yang lebih luas dibandingkan dengan Entity teory. Akuntabilitas yang dimaksud adalah akuntabilitas kepada tuhan, manusia, dan alam. Bentuk akuntabilitas semacam ini berfungsi sebagai tali pengikat agar akuntansi syariah selalu terhubung dengan nilai-nilai yang dapat membangkitkan kesadaran ke-Tuhanan. Konsekuensi dari diterimanya SET sebagai dasar dari pengembangan teori akuntansi syariah adalah pengakuan income dalam bentuk nilai tambah (value-added), bukan income dalam pengertian laba (profit), sebagaimana yang diadopsi Entity Theory. ${ }^{2}$

Akuntansi pada dasarnya akan selalu berhubungan dengan distribusi aktiva produktif, hak residual atas aktiva pada saat likuidasi, dan hak ekuitas (kekayaan) pada perusahaan yang sedang berjalan baik. Kesemuanya ini merupakan tujuan penting yang hendak dicapai dalam penyajian value added statement atau laporan nilai tambah, yang dalam teori akuntansi konvensional dikenal sebagai laporan laba rugi.

Mengacu pada penelitian Wahyudi (2005) dengan judul Analisis Perbandingan Kinerja Keuangan Bank Syariah Menggunakan Pendekatan Laba Rugi dan Nilai Tambah, Penelitian tersebut menghasilkan bahwa kinerja keuangan PT. BSM tahun 2003 dan 2004 yang dihitung dengan menggunakan pendekatan nilai tambah menghasilkan nilai rasio yang lebih besar jika dibandingkan dengan menggunakan pendekatan laba rugi. Hanya saja sebaiknya pada saat sebelum melakukan perhitungan rasio kinerja keuangan bank syariah, terlebih dahulu hitung berdasarkan nilai sekarang sehingga diperoleh hasil penelitian yang tidak hanya handal secara konseptual dan juga empiris. ${ }^{3}$

\section{B. Rumusan Masalah}

Berdasarkan latar belakang diatas maka yang menjadi rumusan masalah adalah :

\footnotetext{
${ }^{2}$ Ibid.,h.7

${ }^{3}$ Ibid.,h.9
} 
1. Bagaimana kinerja keuangan Bank Rakyat Indonesia Syariah berdasarkan laporan laba rugi dan laporan nilai tambah jika diukur menggunakan rasio ROA, ROE, LBAP, NPM?

2. Bagaimana perbedaan kinerja keuangan Bank Rakyat Indonesia Syariah dengan menggunakan laporan laba rugi dan nilai tambah?

C. Defenisi Operasional

Untuk menghindari kekeliruan penafsiran terhadap Value Added Statement, kata dan istilah teknis yang terdapat dalam judul, maka penulis merasa perlu untuk mencantumkan defenisi operasional dan ruang lingkup penelitian dalam skripsi ini. Judul penelitian ini adalah Analisis perbandingan kinerja keuangan PT Bank BRISyariah menggunakan Laporan Laba Rugi dan Laporan Nilai Tambah dengan menggunakan rasio keuangan ROA, ROE, LBAP, NPM pengertian antara lain :

1. Rasio adalah suatu angka yang menunjukkan hubungan antar suatu unsur dengan unsur lainnya dalam laporan keuangan.

2. Laporan Keuangan adalah catatan informasi keuangan suatu perusahaan pada suatu periode akuntansi yang dapat digunakan untuk menggambarkan kinerja perusahaan tersebut.

3. Laporan Laba Rugi, adalah laporan keuangan yang menggambarkan hasil-hasil usaha yang dicapai selama periode tertentu.

4. Laporan Nilai Tambah, adalah Laporan pendistribusian dalam bentuk zakat, infaq, sedekah, pajak (pemerintah), pegawai (gaji), pemilik (deviden), dan dana yang ditanam kembali.

5. Nilai tambah adalah kenaikan nilai kekayaan yang dihasilkan dengan penggunaan yang produktif dari seluruh sumber-sumber kekayaan perusahaan oleh seluruh tim yang ada termasuk pemilik modal, karyawan, kreditur, dan pemerintah. 
6. Rasio Return On Assets(ROA), adalah rasio yang menggambarkan kemampuan bank dalam mengelola dana yang diinvestasikan dalam keseluruhan aktiva yang menghasilkan keuntungan. Adapun rumusnya sebagai berikut :

7. Laba bersih adalah laba (atau rugi) yang diperoleh bank setelah dikurangi dengan pajak.

8. Total aktiva adalah total aktiva yang dimiliki oleh bank baik aktiva lancar maupun aktiva tetap.

9. Aktiva Tetap adalah aktiva berwujud yang diperoleh dalam bentuk siap pakai atau dengan dibangun lebih dahulu, yang digunakan dalam operasi perusahaan, tidak dimaksudkan untuk dijual dalam rangka kegiatan normal perusahaan dan mempunyai masa manfaat lebih dari satu tahun.

10. RasioReturn On Asset(ROE), adalah perbandingan antara pendapatan bersih dengan rata-rata modal atau investasi para pemilik bank. Adapun rumusnya sebagai berikut :

11. Total modal adalah hak residual atas aset entitas syariah setelah dikurangi semua kewajiban dan dana syirkah temporer.

12. Rasio perbandingan antara total laba bersih dengan aktiva produktif. Adapun rumusnya sebagai berikut :

13. Laba Bersih adalah kelebihan seluruh pendapatan atas seluruh biaya untuk suatu periode tertentu setelah dikurangi pajak penghasilan yang disajikan dalam bentuk laporan laba rugi.

14. Aktiva produktif adalah penanaman dana bank baik dalam rupiah maupun valuta asing dalam bentuk kredit, surat berharga, penempatan dana antar bank, penyertaan, komitmen dan kontijensi pada transaksi rekening administratif.

15. RasioNet Profit Margin(NPM) adalah gambaran efisiensi suatu bank dalam menghasilkan laba. Adapun rumusnya sebagai berikut : 
16. Pendapatan adalah total penghasilan yang didapat oleh bank.

17. Laba adalah selisih pendapatan dengan beban apabila pendapatan melebihi jumlah beban yang dikeluarkan.

18. Bank Syariah, adalah Bank yang menjalankan kegiatan usahanya berdasarkan prinsip syariah.

\section{METODE PENELITIAN}

Dalam penelitian ini menggunakan metode kualitatif. Data yang diperoleh kemudian dianalisis dengan menggunakan analisis deskriptif dimana peneliti membandingkan hasil ROA, ROE, LBAP, dan NPM pada laporan keuangan perbankan syariah yang menggunakan laporan laba rugi dan nilai tambah.

\section{Tinjauan pustaka}

Proprietary theory dan entity theory tidak akan mampu menampung kemajemukan masyarakat (stakeholders) dan bisnis pada saat ini. Untuk mengatasi hal tersebut maka diperlukan alternatif yang lebih tepat dan sesuai dengan lingkungannya seperti yang disampaikan oleh (Slamet 2001) adalah enterprise theory.

Mengenai enterprise theory ini Triyuwono berpendapat bahwa teori tersebut lebih lengkap dibandingkan dengan teori yang lain. Karena ia melingkupi aspek sosial dan pertanggungjawaban. Berbeda dengan entity theory yang memusatkan perhatian hanya pada kelompok pemilik sehingga hampir seluruh aktivitas perusahaan diarahkan guna memenuhi kesejahteraan pemilik. Enterprise theory dalam hal ini memiliki tidak hanya sifat egois namun juga sudah mulai mengadopsi sifat altruistik.

Dalam enterprise theory, pihak-pihak yang memiliki kepentingan harus diperhatikan dalam penyajian informasi keuangannya, bukan hanya mementingkan informasi bagi pemilik, tetapi juga pihak lainnya yang memberi kontribusi langsung maupun tidak langsung kepada eksistensi perusahaan atau lembaga (Harahap 2002). Semua partisipan menanggung segala aspek kegiatan bersama sehingga mereka disebut secara bersama sebagai stakeholders yang 
terdiri atas manager, pelanggan, pemerintah, dan masyarakat. Perusahaan berfungsi sebagai alat, pengikat atau pusat (nexus) kegiatan.

Pandangan enterprise theory dilandasi oleh gagasan bahwa perusahaan berfungsi sebagai institusi sosial yang mempunyai pengaruh ekonomis luas dan kompleks sehingga darinya dituntut pertanggungjawaban sosial. Perusahaan tidak dapat lagi dijalankan untuk kepentingan pemegang saham semata-mata walaupun para pemegang saham mempunyai hak yuridis sebagai pemilik, kepentingan para stakeholders secara bersama demi berlangsungnya dan kemakmuran perusahaan harus didahulukan.

\section{Syariah Enterprise Theory}

Dalam syariah enterprise theory menurut Triyuwono menjelaskan bahwa yang paling penting dan harus paling mendasari dalam setiap penetapan konsepnya adalah Allah SWT sebagai Pencipta dan Pemilik Tunggal dari seluruh sumber daya yang ada didunia ini. Maka yang berlaku dalam syariah enterprise theory adalah Allah sebagai sumber utama, karena Dia adalah Pemilik Tunggal dan Mutlak dari seluruh sumber daya yang ada didunia ini. Sedangkan sumber daya yang memiliki oleh para stakeholders pada prinsipnya adalah amanah dari Allah SWT yang didalamnya melekat sebuah tanggung jawab untuk menggunakan dengan cara dan tujuan yang telah ditetapkan ${ }^{4}$.

Dengan demikian, dalam pandangan syariah enterprise theory, distribusi kekayaan (wealth) atau nilai tambah (value added) tidak hanya berlaku pada para partisipan yang terkait langsung dalam, atau partisan yang memberikan kontribusi kepada, operasi perusahaan; seperti pemegang saham, kreditor, karyawan, dan pemerintah, tetapi pihak lain yang tidak terkait langsung dengan bisnis yang dilakukan perusahaan, atau pihak yang tidak memberikan kontribusi keuangan dan skill. Artinya, cakupan akuntansi dalam shariah enterprise theory

${ }^{4}$ Ibid. 
tidak terbatas pada peristiwa atau kejadian yang bersifat reciprocal antara pihak-pihak yang terkait langsung dalam proses penciptaan nilai tambah, tetapi juga pihak lain yang tidak terkait langsung. Pemahaman ini tentu membawa perubahan penting dalam terminologi enterprise theory yang meletakkan premisnya untuk mendistibusikan kekayaan (wealth) berdasarkan kontribusi para partisipan, yaitu partisipan yang memberikan kontribusi atau keterampilan. ${ }^{5}$ Pada prinsipnya syariah enterprise theory memberikan bentuk pertanggungjawaban utamanya kepada Allah SWT (vertikal) yang kemudian dijabarkan lagi pada bentuk pertanggungjawaban (horizontal) pada umat manusia dan lingkungan alam. Bentuk akuntabilitas semacam ini berfungsi sebagai tali pengikat agar akuntansi syariah selalu terhubung dengan nilai-nilai yang dapat "membangkitkan kesadaran keTuhanan"6. Syariah enterprise theory yang dibangun berdasarkan metafora amanah dan metafora zakat, lebih menghendaki keseimbangan antara sifat egoistik dan altruistik dibanding dengan entity theory. Sementara entity theory lebih mengedepankan sifat egoistiknya daripada sifat altruistik (kepuasan bukan dalam bentuk materi, tapi secara spiritual).

\section{PEMBAHASAN HASIL PENELITIAN}

Pengukuran kinerja keuangan Bank

Menurut Ikatan Akuntansi Indonesia (IAI, 1996), kinerja perusahaan dapat diukur dengan menganalisa dan mengevaluasi laporan keuangan. Informasi yang digunakan dalam mengukur kinerja keuangan adalah informasi keuangan (financial information), yaitu informasi akuntansi manajemen dan informasi akuntansi keuangan. Informasi posisi keuangan dan kinerja keuangan di masa lalu seringkali digunakan sebagai dasar untuk memprediksi posisi keuangan dan kinerja keuangan di masa depan dan hal-hal lain yang langsung menarik perhatian pemakai seperti pembayaran dividen, upah, pergerakan harga sekuritas dan 
kemampuan perusahaan untuk memenuhi komitmennya ketika jatuh tempo.Kinerja keuangan bank merupakan bagian dari kinerja bank secara keseluruhan. Kinerja (Performance) bank secara keseluruhan merupakan gambaran prestasi yang dicapai bank dalam operasionalnya, baik menyangkut aspek keuangan, pemasaran, penghimpunan dan penyaluran dana, teknologi maupun sumber daya manusia. ${ }^{7}$

Menurut Warsono (2003:24), “ada lima macam alat ukur atau metode yang bisa digunakan untuk mengukur kinerja keuangan sebuah perusahaan, yaitu analisis rasio keuangan, analisis rasio keuangan yang dimodifikasi, Analisis Economic Value Added, Analisis Capital, Asset, Management risk, Earning and Lliquidity(CAMEL),dan Analisis Balance Scorecard". Analisis rasio sangat bermanfaat bagi manajemen untuk perencanaan dan pengevauasian prestasi atau kinerja (performance) perusahaannya bila dibandingkan dengan rata-rata industri, sedangkan bagi para kreditor dapat digunakan untuk memperkirakan potensi risiko yang akan dihadapi dikaitkan dengan adanya jaminan kelangsungan pembayaran bunga dan pengembalian pokok pinjamannya.Wild, Subramanyam dan Hasley (2005:16) menyatakan bahwa analisis keuangan (financial analysist) merupakan penggunaan laporan keuangan untuk menganalisis posisi dan kinerja keuangan perusahaan dan untuk menilai kinerja keuangan di masa depan.Menurut Munawir, 2002, teknik analisis rasio keuangan yang biasa digunakan,yaitu: (1) teknik analisis cross sectional, adalah analisis rasio dengan membandingkan antar informasi atau data untuk satu periode, kemudian hasilnya dibandingkan dengan rasio pembanding antara lain rasio pada perusahaan sejenis atau ratarata industri, (2) teknik analisis time seriesatau trend, adalah analisis rasio keuangan untuk beberapa periode sehingga akan terlihat prestasi perusahaan tersebut cenderung meningkat, menurun atau cenderung konstan dalam beberapa periode tersebut.

\section{${ }^{7}$ http.//repository.usu.ac.id/bitstream/123456789/26406/4/Chapter\%20Il.pdf}


Seperti yang telah dipaparkan diatas, maka pengukuran rasio keuangan dapat digunakan untuk mengetahui kinerja suatu bank. Pengukuran kinerja bank digunakan untuk mengetahui tentang baik-buruknya operasional bank serta seberapa sehatkah bank yang bersangkutan untuk dapat menjalankan fungsi-fungsi perbankan.

Kinerja keuangan PT Bank BRI Syariah

Untuk mengetahui bagaimana gambaran mengenai kinerja keuangan di PT Bank BRI Syariah , maka peneliti menyajikan data tersebut dalam bentuk tabel yang telah diolah sebagai berikut:

Tabel 4.3

Kinerja keuangan PT Bank BRI Syariah

\begin{tabular}{|c|c|c|c|c|}
\hline Tahun & ROA & ROE & LBAP & NPM \\
\hline 2013 & $1.15 \%$ & $10.20 \%$ & $0.79 \%$ & $0.74 \%$ \\
\hline 2014 & $0.08 \%$ & $0.44 \%$ & $0.01 \%$ & $0.01 \%$ \\
\hline 2015 & $0.76 \%$ & $6.20 \%$ & $0.51 \%$ & $0.50 \%$ \\
\hline
\end{tabular}

Sumber: Data yang telah diolah

Dari tabel diatas dapat diketahui bahwa PT Bank BRI Syariah mempunyai laporan keuangan dalam hal ini rasio keuangan profitabilitas yang meliputi ROA, ROE, LBAP, dan NPM pada tahun 2013-2015 yang mengalami penurunan dan kenaikan. Dimana pada tahun 2014 mengalami penurunan yang sangat signifikan, akan tetapi pada tahun berikutnya mengalami kenaikan meski belum maksimal, itu ditunjukan pada kenaikan yang belum mencapai angka seperti tahun sebelumnya pada saat mengalami penurunan (tahun 2013).

Laporan Laba rugi \& Nilai tambah PT Bank BRI Syariah

Sebagaimana rumusan masalah pada skripsi ini yaitu untuk mengetahui bagaimana kinerja keuangan Bank Rakyat Indonesia Syariah berdasarkan laporan laba rugi dan laporan nilai tambah jika diukur menggunakan rasio ROA, ROE, LBAP, dan NPM maka peneliti akan menyajikan hasil pengolahan yang menunjukan laporan laba rugi dan nilai tambah PT Bank BRI Syariah pada periode 2013-2015 untuk nantinya dapat dianalisis, yaitu sebagai berikut: 
Tabel 4.4

Laporan laba rugi \& nilai tambah

\begin{tabular}{|c|c|c|}
\hline Tahun & Laba (rugi) & Nilai tambah \\
\hline 2013 & Rp. $129.568 .000 .000,-$ & Rp. 55.992 .000 .000 \\
\hline 2014 & Rp. $2.822 .000 .000,-$ & Rp. 1.694 .000 .000 \\
\hline 2015 & Rp. $169.069 .000 .000,-$ & Rp. $73.583 .000 .000,-$ \\
\hline
\end{tabular}

Sumber: data yang telah diolah

Berdasarkan tabel diatas menunjukan bahwa laporan laba rugi pada PT Bank BRI Syariah mengalami penurunan yang signifikan pada tahun 2014, dan pada tahun berikutnya mengalami kenaikan kembali. Begitupun yang ditunjukan pada laporan nilai tambah, bahwa pada tahun 2014 mengalami penurunan yang signifikan akan tetapi pada tahun berikutnya mengalami kenaikan yang signifikan.

\section{KESIMPULAN}

Berdasarkan judul penelitian, latar belakang masalah, rumusan masalah, pembahsahan dan hasil pada penelitian yang telah dilakukan secara pustaka (Library Research) maka peneliti akan memberi kesimpulan sebagai berikut:

Kinerja keuangan PT Bank BRISyariah berdasarkan laporan raba-rugi pada periode 2013, 2014, dan 2015 dapat dikatakan mengalami ketidak stabilan, artinya bahwa kinerja keuangan PT Bank BRISyariah dalam 3 periode tersebut tidak stabil diaman pada tahun 2014 
mengalami penurunan yang sangat signifikan sedangkan pada tahun berikutnya (2015) mengalami kenaikan yang cukup signifikan pula.

\section{DAFTAR PUSTAKA}

Abdul Karim, Adiwarman, Bank Islam “Analisis Fiqih dan Keuangan”, Edisi III: Jakarta: PT. RajaGrafindo Persada,2008.

Damastuti, Isnaini Endah, Analisis Perbandingan Kinerja Keuangan Bank Syariah Dengan Menggunakan Income Statement Approach dan Value Added statement Approach, Semarang: Skripsi, 2010.

Ghosali, Imam,Aplikasi Analisis Multivariate Dengan Program Spss, Semarang: Undip 2005.

Harahap, Sofyan Safri, Menuju Perumusan Teori Akuntansi Islam, Jakarta: Pustaka Quantum, 2006 http://brisyariah.co.id

http://repository.usu.ac.id/bitstream/123456789/26406/4/Chapter\%20II.pdf

Mulawarman, Aji Dedi. Akuntansi syariah, Teory, Konsep dan Laporan Keuangan, Jakarta, Publishing Company,2009

Muthaher, Osmad. Akuntansi Perbankan Syariah, Cet.I; Yogyakarta, Graha Ilmu, 2012

Nurhayati, Sri dan Wasilah, Akuntansi Syariah di Indonesia, Cet.II; Jakarta: Salemba Empat, 2008

Reza, M. Amrullah Putra Tara, Analisis Perbandingan Kinerja Keuangan Perbankan Syariah Menggunakan Pendekatan Laba Rugi (Income Statement) dan Nilai Tambah (Value Added Statement), Semarang: Skripsi, 2014.

Soemitra, Andri, M.A, Bank dan Lembaga Keuangan Syariah, Edisi I, Cet.II; Jakarta: Kencana Prenada Media Group, 2010

Sugiono, Metode Penelitian Kuantitatif, Kualitatif, dan Kombinasi (Mixed Methods), Bandung: Alfabeta CV.

Suwanto, Perbandingan Kinerja Keuangan Bank Syariah dengan Pendekatan Income Statement Approach dan Value Added Approach, Semarang: Journal, 2011.

Triyuwono, Iwan, Respektif Metodologi dan Teori Akuntansi Syariah, Jakarta: PT. Raya Grafindo Persada, 2006.

Usman, Rachmadi, Aspek Hukum Perbankan Syariah Di Indonesia, Jakarta: Sinar Grafika, 2012. 